\title{
Assessing the reasoning skills of biology students in selected senior high schools in the central region of Ghana
}

\author{
Emmanuel Eshun ${ }^{1}$, Charles Agyei Amoah ${ }^{2}$ \\ ${ }^{1}$ Presbyterian College of Education, Science Department, Akropong, Ghana \\ ${ }^{2}$ OLA College of Education, Science Department, Cape Coast, Ghana
}

\begin{abstract}
The purpose of the study was to determine the competency level of senior high school (SHS) biology students in reasoning skills and see whether the type of school a student attends gender has influence on the proficiency in demonstrating reasoning skills when SHS biology students are engaged in laboratory work. The study adopted the "Basic Skills Assessment" approach. The population for the study was 665 SHS 3 elective biology students offering General Science programme for the 2015/ 2016 academic year in the Cape Coast Metropolis in the Central Region of Ghana. The sample consisted of 114 students from both single sex and co-educational Senior High Schools (SHS) offering elective biology for the West African Secondary School Certificate Examinations (WASSCE). Purposive sampling was used to select the schools which participated in the study. One single-sex girls' school, one single-sex boys' school and one coeducational (mixed) school were selected. The findings from the study revealed that school type was found to be significantly related to the performance of students at reasoning skills. However, singlesex boys did not differ significantly from mixed schools. Gender was found not to be significantly related to the performance of the students at reasoning skills. However, greater proportion of males exhibited same levels of reasoning skills than their female counterparts. It was recommended that female biology students must be made to do more laboratory work that involves reasoning to improve their reasoning skills.
\end{abstract}

Key Words: Reasoning skill, Dichotomous, Laboratory work, Basic skills assessment.

\section{Introduction}

Reasoning as a science process skills are major contributors to academic and everyday life success. Science education reform document have long emphasised helping students to develop scientific reasoning skills as a major goal for science education (American Association for the Advancement of Science, 1998). Educators believe that reasoning skills play an important role in students' ability to develop scientific understanding and conduct scientific investigation. According to Holyoak and Morrison (2005) scientific reasoning skills mark the development of adolescent cognition and are often demanded for effective decisionmaking and problem-solving. Reasoning skills are also intrinsic to the process of knowledge acquisition and conceptual change (Kuhn as cited in Zeineddin \& Fouad, 2010).

Scientific reasoning is complex in nature (Schunn \& Anderson, 1999). Holyoak and Morrison (2005) see reasoning as a specific type or branch of thinking that involves drawing inferences from initial premises and is closely related to judgement, decision-making and problem-solving. Kuhn (2004) argued that scientific reasoning requires more than the strategies of controlling variables and inductive causal inferences, which have been dominant in reasoning studies. According to Kuhn (2004), scientific reasoning is a conscious, purposeful knowledge seeking-process that is social in nature. It is a process that people go through in order to revise their ideas and build new understandings. The heart of this reasoning process is a coordination of theory and evidence, which does not only mean revising the theory in the light of the evidence, but differentiating between and contemplating both. Successful theory-evidence coordination requires questioning existing theories, seeking contradictory evidence and eliminating alternative explanations. Lawson (2005) regarded formal or advanced reasoning as largely hypothetico-deductive in structure and consisting of a number of interrelated aspect or schemata that functions independently depending on the situation or task. 


\section{Statement of the Problem}

One of the general aims of the Teaching Syllabus for Biology (Senior High School) emphasises the "development of practical skills required to work with scientific equipment, biological materials and living things" (Ministry of Education, Science and Sports [MOESS], 2008, p.ii). In line with this, the need to teach Biology is to "guide and inculcate in the learner skills in observing and measuring, formulating hypothesis, predicating and designing, investigating, recording data and interpreting results, drawing conclusions and communicating them" (MOESS, 2008, p.ii). However, the West African Examination Council (WAEC) Chief Examiner for Biology have over the years (20082015) reported of students' weaknesses in scientific skills such as planning, performing, reasoning and predicting. Saddler and Tai (2001) asserted that the low performance of students in the reasoning task could be attributed to over reliance on a model isolationist pedagogy with an excessive amount of reliance on textbooks and rote problem solving, even though this type of isolated learning have been found to be detrimental to the success of students in science. It is not clear whether students' demonstration of inadequate competency in scientific skills of reasoning lies with the type of school the students attend or the frequency with which laboratory work is organised. This has necessitated the need to assess the reasoning skills of the biology students at senior high school level to determine their competency level.

\section{Purpose of the Study}

The purpose of the study was to determine the competency level of senior high school (SHS) biology students in reasoning skills and see whether the type of school a student attends gender has influence on the proficiency in demonstrating reasoning skills when SHS biology students are engaged in laboratory work.

\section{Research Question}

1. What is the relationship between the type of school a student attend and the reasoning skills of SHS biology students?

2. Which gender shows more proficiency in reasoning skills?

\section{Methodology}

The study adopted the "Basic Skills Assessment" approach. "Basic Skills Assessment" is psychological assessment which is basically a judgemental process whereby a broad range of information, often including the results of psychological tests, is integrated into a meaningful understanding of a particular person. Psychological testing is thus a narrower concept referring to the Psychometric aspects of a test, the actual administration and scoring of the test, and the interpretation made of the scores (Domino \& Domino, 2006).

Psychometric tests are standardised tests designed to evaluate psychological functions; intelligence, ability, personality, interests and values. They are pen and paper or computer based and are taken under standardised conditions. The results are quantified by reference to a scale derived from research and the answers are objectively marked and analysed to produce a score or profile. The "basic skills assessment" approach was used because it is a test of minimum competency in basic skills. Students also engage in hands-on activities that are scored as right or wrong or dichotomously.

The population for this study was 665 SHS 3 elective biology students offering General Science programme for the 2015/ 2016 academic year in the Cape Coast Metropolis in the Central Region of Ghana. There were seven schools offering the general science programme and were classified as Single-sex boys, Single-sex girls and Mixed school. There were three single-sex boys' schools, two single-sex girls' schools and two mixed (coeducational) schools.

The sample consisted of 114 students from both single sex and co-educational Senior High Schools (SHS) offering elective biology for the West African Secondary School Certificate Examinations (WASSCE).

Purposive sampling was used to select the schools which participated in the study. One single-sex girls' school, one single-sex boys' school and one co-educational (mixed) school were selected.

The research instrument that was developed for the study was performance assessment tasks. This was a researcher-developed instrument. A reasoning task was developed where students were presented with a data on an experimental result and were asked to give reasons for the experimental results recorded and hence state what could be derived from the experiment. Kuder-Richardson (K-R 20) estimate was used to establish the reliability since the tasks were scored dichotomously with an alpha value of 0.89 .

\section{Results and Discussion}

A one-way analysis of variance (ANOVA) was conducted to explore the influence of the type of school on reasoning skills. Subjects were divided 
into three groups (Group 1: Single-sex boys; Group 2: Single-sex girls; Group 3: Mixed school). There was a statistically significant difference at the $\mathrm{p}<$ 0.05 level in reasoning skills for the three groups. ( F $(2,111)=5.99, \mathrm{p}=.003)$. The actual difference in mean scores between the groups was medium. The effect size calculated using eta squared, was 0.097. Post-hoc comparisons using Tukey HSD test indicated that the mean score for the Single-sex girls $(\underline{\mathrm{M}}=3.38, \underline{\mathrm{SD}}=1.50)$ was significantly different from mixed school $(\underline{\mathrm{M}}=2.82, \underline{\mathrm{SD}}=1.51)$ and Single-sex boys ( $\underline{\mathrm{M}}=3.85, \underline{\mathrm{SD}}=1.08)$. However, single-sex boys did not differ significantly from mixed schools.

\section{Table 1: Means and Standard deviations for the School types}

\begin{tabular}{lrcc}
\hline Type of school & N & Mean & Standard deviation \\
\hline Single-sex boys & 40 & 3.85 & 1.08 \\
Single-sex girls & 29 & 3.38 & 1.50 \\
Mixed school & 45 & 2.82 & 1.51 \\
\hline Total & $\mathbf{1 1 4}$ & $\mathbf{3 . 3 2}$ & $\mathbf{1 . 4 3}$
\end{tabular}

From Table 1, it was found that the mean scores of the single-sex schools were significantly better than the mixed schools. Mean scores of 3.85, 3.38 and 2.82 were obtained for single-sex boys, single-sex girls and mixed schools respectively. Dhindsa \& Chung (2003) report that the mean achievement scores in science for boys in the single-sex schools were significantly better than those in coeducational schools. This result demonstrates that, on the average, the science achievements of male as well as female students in single-sex schools were
This finding of the study suggests that in reasoning skills, single-sex boys, single-sex girls and mixed schools performed at different levels. It also indicates that the performance of single-sex girls in reasoning skills is higher than single-sex boys and mixed schools. Single-sex boys' school however do not outperformed mixed schools in the reasoning skills because there was no statistical significant difference between the two schools.

The means and standard deviations for the school types is shown on Table 1 .

Table 2: Analysis of Variance of the School types

\begin{tabular}{llcccc}
\hline Value label & $\begin{array}{c}\text { Sum of } \\
\text { Squares }\end{array}$ & $\mathrm{df}$ & $\begin{array}{c}\text { Mean } \\
\text { square }\end{array}$ & $\mathrm{F}$ & $\mathrm{p}$ \\
\hline Between Groups & 22.49 & 2 & 11.24 & 5.99 & .003 \\
Within Groups & 208.51 & 111 & 1.88 & & \\
\hline Total & $\mathbf{2 3 0 . 9 9}$ & $\mathbf{1 1 3}$ & & & \\
\hline
\end{tabular}

A study by Valanides (1996) to determine the formal reasoning abilities of $7^{\text {th }}-8^{\text {th }}$ and $9^{\text {th }}$ grade students found out that there were no differences in how males and females engage in reasoning processes. This finding of Valanides (1996) seem not to agree with the finding of this study that single-sex girls' competence or proficiency in moderately better than that of students in coeducational schools. The findings of this research on the reasoning skills seem to agree with the finding of Dhinsa \& Chung (2003). The finding of this research is also congruent to a finding by Pollard (1999) that grade point average were higher for both girls and boys in single-sex Mathematics and Science classes than in mixed-sex classes.

Table 2 shows the analysis of variance of school types. reasoning skills is statistically significant from that of single-sex boys.

Table 3 shows Post-hoc comparisons of school types using Tukey HSD Test. 
Table 3: Post-hoc comparisons of school types using Tukey HSD Test

\begin{tabular}{llll}
\hline Type of school & type of school & mean difference & $\mathrm{p}$ \\
\hline Single sex boys & Single sex girls & .47 & .34 \\
& Mixed school & $1.028^{*}$ & .002 \\
Single sex girls & Single-sex boys & -.47 & .33 \\
& Mixed schools & .56 & .33 \\
Mixed school & Single-sex boys & $-1.03^{*}$ & .29 \\
& Single-sex girls & -.56 & .33 \\
\hline
\end{tabular}

$* \mathrm{P}=0.05$

From Table 3, Single-sex girls differ significantly from mixed schools and single-sex boys. However, single-sex boys did not differ significantly from mixed schools.

According to Young and Fraser (1994) the type of school from which the students came is one of the factors that influence science achievement.

Similarly, the finding of this research has shown that the type of school the students attended determined the performance of students on the reasoning skills.

\section{Research Question 2: Influence of Gender on Reasoning Skills}

Mann-Whitney U test was conducted to find out which gender shows more proficiency in reasoning skills and this is presented on Table 4.

Table 4: Mann-Whitney U test of Reasoning Skills by Gender

Value label Reasoning Skills

\begin{tabular}{lc} 
Mann-Whitney U & 1305.00 \\
$\mathrm{Z}$ & -1.53 \\
$\mathrm{P}$ - value & 0.13 \\
\hline
\end{tabular}

Significance: $\mathrm{P}>0.05$

From Table 4, the result of the test was not significant, $\underline{z}=-1.53, p=0.13$. The results of this study is consistent with the result of the studies conducted by Amoah (2011); Sungur and Tekkaya (2003) which revealed that boys and girls do not differ significantly in their reasoning ability in human circulatory system even though boys scored higher than girls. A study by Valanides (1996) to determine the formal reasoning abilities of students revealed that there were no differences in how males and females engage in reasoning processes and this also confirms the result from this study. The low performance of the females could be due to the fact that females naturally resist some type of inquiry and support the traditional paradigm because it allows them to maintain their "good student abilities"(Carlone, 2004). However, Johnson (2001) found out from a study that females performed better than the males in the skills of reasoning.

The mean ranks for gender on reasoning skills are shown on Table 5.

Table 5: Mean ranks for Gender on Reasoning Skills

\begin{tabular}{llcc}
\hline Sex & N & Mean Rank & Sum of Ranks \\
\hline Male & 68 & 61.31 & 4169.00 \\
Female & 46 & 51.87 & 2386.00 \\
\hline Total & $\mathbf{1 1 4}$ & & \\
\hline
\end{tabular}


From Table 5, the mean ranks revealed that males scored higher on reasoning task than the females. The males had a mean rank of 61.31 while the females had a mean rank of 51.87. Although results from Table 4 revealed that there were no evidence of a difference in how males and females engage in reasoning processes, an inspection of the mean ranks has shown that males score higher on biological tasks that require logical thinking, proportional reasoning and drawing inferences from a given data.

\section{Conclusion}

The findings from the study revealed that school type was found to be significantly related to the performance of students at reasoning skills. However, single-sex boys did not differ significantly from mixed schools.

It is also concluded that gender was found not to be significantly related to the performance of the students at reasoning skills. However, greater proportion of males exhibited same levels of reasoning skills than their female counterparts.

\section{Recommendation}

1. Female biology students must be made to do more laboratory work that involves reasoning to improve their reasoning skills.

\section{References}

[1] American Association for the Advancement of Science. (1998). National science education standards. Washington, DC: National Academy Press.

[2] Amoah, C. A. (2011). Assessing laboratory skills of biology students in selected senior high schools in Ghana. Unpublished Mphil Thesis. University of Cape Coast, Cape Coast.

[3] Carlone, H. (2004). The cultural production of science in reformed-based physics: Girls access, participation and resistance. Journal of Research in Science Teaching, 37 (5), 441-458.

[4] Dhindsa, H., \& Chung, G. (2003). Attitudes and achievement of Bruneian science students. International Journal of Science Education, 25, 907-923

[5] Domino, G., \& Domino, M. L. (2006). Psychological testing: An introduction $\left(2^{\text {nd }} e d\right.$.). London: Cambridge University Press

[6] Holyoak, K. J., \& Morrison, R. G. (2005). The Cambridge handbook of thinking and reasoning: A reader's guide. In K. J. Holyoak \& R. G. Morrison (Eds.), Cambridge Handbook of Thinking and Reasoning, New York: Cambridge University Press
[7] Johnson, A. E. (2001). Assessing laboratory skills of physics students in selected Senior secondary school topics in mechanics. Unpublished Masters Thesis, University of Cape Coast, Cape Coast.

[8] Kuhn, D. (2004). What is scientific thinking and how does it develop? In U, Goswami (Ed.), Blackwell handbook of childhood cognitive development, 371-393, Malden MA: Blackwell

[9] Lawson, A. (2005). Scientific reasoning and epistemological commitments: Coordination of theory and evidence among College Science Students. Retrieved March 2011, from Microbelibrary.org/ASMonly

[10]Ministry of Education, Science and Sports (MOESS) (2008). Teaching syllabus for biology (Senior High School). Accra: CRDD

[11]Pollard, D. (1999). Single sex education. WEEA Digest. ERIC document number 435553. Retrieved June 2010, from ERIC database.

[12]Saddler, P. M., \& Tai, R. H. (2001). Success in introductory college physics: The role of high school preparation. Science Education, 85(2), 111-136.

[13]Schunn, C. D., Anderson, J. R. (1999). The Generality/ specificity of expertise in scientific reasoning. Cognitive Science, 23 (3), 337-370.

[14]Sungur, S., \& Tekkaya, C. (2003). Students' achievement in human circulatory system unit: The effect of reasoning ability and gender. Journal of Science Education and Technology, 12 (1), 59-64.

[15] Valanides, N. C. (1996). Formal reasoning and science teaching. School Science and Mathematics, 96(2), 99-107

[16]West African Examinations Council (WAEC) (2008) Chief examiners' report for general science programme. Accra: Waecprint.

[17]West African Examinations Council (WAEC) (2009). Chief examiners' report for general science programme. Accra: Waecprint.

[18] West African Examinations Council (WAEC) (2010). Chief examiners' report for core and universal subjects. Accra: Waecprint.

[19]West African Examinations Council (WAEC) (2011). Chief examiners' report for core and universal subjects. Accra: Waecprint

[20]West African Examinations Council (WAEC) (2012). Chief examiners' report for core and universal subjects. Accra: Waecprint

[21]West African Examinations Council (WAEC) (2013). Chief examiners' report for core and universal subjects. Accra: Waecprint 
[22]West African Examinations Council (WAEC) (2014). Chief examiners' report for core and universal subjects. Accra: Waecprint

[23]West African Examinations Council (WAEC) (2015). Chief examiners' report for core and universal subjects. Accra: Waecprint

[24]Young, D. J., \& Fraser, B. J. (1992). School effectiveness and science achievement: Are there any sex differences? Paper presented at the Annual Meeting of the American Research Association, San Francisco, CA

[25]Zeineddin, A., \& Foud, A. K. (2010). Scientific reasoning and epistemological commitments: Coordination of theory and evidence among College Science Students. Journal of Research in Science Teaching, 47(9), 1064-1093. 